Jurnal Analis Medika Biosains (JAMBS)

Vol.7, No.2, September 2020, pp. 87 - 92

ISSN: 2656-2456 (Online)

ISSN: 2356-4075 (Print)

\title{
Inventarisasi Bahan Tambahan Makanan (BTM) Penyebab Positif Palsu Pada Uji Kualitatif Boraks Dengan Filtrat Ubi Ungu (Ipomoea Batatas L)
}

Arista Suci Andini' ${ }^{1}$, Syuhriatin $^{2}$, Diaul Maftuha ${ }^{3}$

${ }^{123}$ Jurusan Biologi, Universitas Islam AL-Azhar, Indonesia

\begin{tabular}{l}
\hline Article Info \\
\hline Article history: \\
Received Feb $19^{\text {th }}, 2020$ \\
Revised Juli $12^{\text {th }}, 2020$ \\
Accepted Juli $28^{\text {th }}, 2020$ \\
\hline
\end{tabular}

Keyword:

Borax

False positive

Purple yam filtrate

\begin{abstract}
Sodium Tetraborate (borax) is a type of food additive (BTM) that functions as a preservative which is prohibited by the Indonesian Ministry of Health. Consumption of foods containing borax can cause brain disorders, liver, fat, kidney, fever, anuria, coma, and even death. Borax qualitative analysis is now beginning to be developed utilizing natural materials, one of which is purple sweet potato. Purple Sweet Potato extract can be used as a borax detector because Purple Sweet Pot extract contains anthocyanin compounds. anthocyanin can detect the presence of borax content in food but often false positives occur in the test. This research was carried out in the Medical Calibration and Medical Support Testing of West Nusa Tenggara Province with the aim to find out BTM which caused the emergence of false positive borak detection. This research was conducted with a qualitative method, by examining the color changes that occur ing each sample of food additives that are used then compared with the standard borax test. Based on the results of research that has been done it can be concluded that food additives with false positive results in the qualitative borax test with purple yam filtrate (I. Batatas L) namely Sodium Benzoate, Monosodium Glutamate, Sodium Tripoliposfat, Sodium Bicarbonate, Bicarbonate, Sodium Carbonate, Sodium Carbonate, Sodium Benzoate, Monosodium Glutamate, Sodium Tripoliposfat, Sodium Bicarbonate, Bicarbonate, Sodium Carbonate, Sodium Carbonate, Sodium Polypospate, and Carboxyl Methyl Cellulose
\end{abstract}

Copyright $\odot$ Jurnal Analis Medika Biosains (JAMBS)

\begin{abstract}
ABSTRAK
Natrium Tetraborate (boraks) merupakan jenis bahan tambahan makanan (BTM) berfungsi sebagai sebagai pengawet yang dilarang Kementerian Kesehatan RI No 235/Menkes/VI/1984. Konsumsi makanan yang mengandung boraks dapat menyebabkan gangguan otak, hati, lemak, ginjal, demam, anuria, koma, bahkan kematian. Analisa kualitatif boraks kini mulai dikembangkan memanfaatkan bahan-bahan alam, salah satunya ubi ungu. Ekstrak Ubi Ungu dapat digunakan sebagai pendeteksi boraks karena ekstrak Ubi Ungu mengandung senyawa antosianin. antosianin dapat mendeteksi adanya kandungan boraks pada makanan akan tetapi sering terjadi positif palsu pada uji. Penelitian ini dilakukan di Kesehatan Pengujian Kalibrasi dan Penunjang Medis Provinsi Nusa Tenggara Barat dengan tujuan untuk mengetahui BTM yang menyebabkan munculnya positif palsu deteksi borak. Penelitian ini dilakukan dengan metode kualitatif, dengan menguji perubahan warna yang terjadi pada masing-masing sampel bahan tambahan makanan yang digunakan yang kemudian dibandingkan dengan standar uji boraks. Berdasarkan hasil penelitian yang telah dilakukan dapat disimpulkan bahwa Bahan tambahan makanan dengan hasil positif palsu pada uji kualitatif boraks dengan
\end{abstract}


Jurnal Analis Medika Biosains (JAMBS)

Vol.7, No.2, September 2020, pp. 87 - 92

ISSN: 2656-2456 (Online)

ISSN: 2356-4075 (Print)

filtrat ubi ungu (Ipomoea Batatas L) yaitu Natrium Benzoat, Monosodium Glutamat, Natrium Tripoliposfat, Natrium Bikarbonat, Bikarbonat, Natrium Karbonat, Natrium Polipospat, dan Carboxyl Methyl Cellulose.

Kata Kunci : Boraks, Positif Palsu, Ubi Ungu

Copyright (C) Jurnal Analis Medika Bio Sains

\section{Pendahuluan}

Natrium Tetraborate atau lebih dikenal dengan boraks merupakan jenis bahan tambahan makanan berfungsi sebagai sebagai pengawet yang dilarang Kementerian Kesehatan RI No 235/Menkes/VI/1984. Konsumsi makanan yang mengandung boraks tidak langsung berakibat buruk terhadap kesehatan tetapi boraks akan menumpuk sedikit demi sedikit karena diserap dalam tubuh konsumen secara kumulatif. Seringnya mengkonsumsi makanan yang mengandung boraks akan menyebabkan gangguan otak, hati, lemak, ginjal, demam, anuria, atau tidak terbentuk urin, koma, merangsang sistem saraf pusat pingsan bahkan kematian ( Widyaningsih dan martini, 2006).

Analisa kualitatif boraks di laboratorium menggunakan uji nyala, uji kertas kunyit atau tumerik, menggunakan larutan perak nitrat, dengan larutan barium klorida, pemanasan boraks dalam tabung pijar, reagensia asam p-nitrobenzena-azo-kromotropat, dan uji biru manitol-bromotimol ( Vogel,1985). Selain itu uji kualitatif yang digunakan untuk mendeteksi boraks didalam makanan dikembangkan dengan memanfaatkan bahan-bahan alami yang di dapatkan dari tumbuhan seperti memanfaatkan senyawa kurkumin pada tanaman kunyit, dimana menurut penelitian Halim (2012) menyatakan bahwa senyawa kurkumin dapat berikatan dengan asam borat yang kemudian akan membentuk komponen resoisanin berwarna merah sehingga dapat digunakan sebagai deteksi boraks.

Pada penelitian (Dwita dkk, 2014) memanfaatkan senyawa antosianin yang ada pada ubi jalar ungu ((Ipomoea Batatas L) sebagai indikator alami untuk mendeteksi adanya boraks di dalam makanan. pH mempengaruhi stabilitas antosianin dan juga warna antosianin. Identifikasi boraks dengan filtrat ubi ungu pada pengukuran $\mathrm{pH}$ larutan memperlihatkan bahwa lamanya penyimpanan larutan yang ditambahkan ekstrak ubi jalar ungu berpengaruh terhadap derajat keasaman larutan tersebut, dimana nilai $\mathrm{pH}$ larutan bertambah seiring dengan lamanya penyimpan sampel larutan. Kemudian pada penelitian (Andriani, , 2015) memanfaatkan senyawa antosianin yang diambil dari ekstrak ubi jalar ungu (Ipomoea Batatas $L$ ) sebagai indikator asam basa.

Ekstrak Ubi Ungu dapat digunakan sebagai pendeteksi boraks karena ekstrak Ubi Ungu mengandung senyawa antosianin. antosianin dapat mendeteksi adanya kandungan boraks pada makanan karena antosianin mampu menguraikan ikatan-ikatan boraks menjadi asam borat dan mengikatnya menjadi kompleks warna biru. Maka, ketika makanan yang mengandung boraks ditetesi oleh ekstrak Ubi Ungu akan mengalami perubahan warna menjadi biru tua (Neny Rochyani dkk, 2017). 
Jurnal Analis Medika Biosains (JAMBS)

Vol.7, No.2, September 2020, pp. 87 - 92

ISSN: 2656-2456 (Online)

ISSN: 2356-4075 (Print)

Beberapa bahan tambahan makanan yang di izinkan oleh Standar Nasional Indonesia pada Peraturan Menteri Kesehatan Republik Indonesia Nomor: 722/Menkes/Per/Ix/88 antara lain yaitu Natrium bikarbonat, Natrium Benzoat, MSG (Monosodium Glutamat), Natrium Karbonat, dan CMC (Carboxymethyl Cellulose) dan Natrium Tripoliposfat memiliki pH 7-9. Dari hasil penelitian (Andriani, 2015) terbentuk perubahan warna menjadi biru dari pH 7-13 sehingga menyebabkan positif palsu pada uji boraks dengan menggunakan filtrat ubi ungu ungu ((Ipomoea Batatas L). Berdasarkan hal tersebut, dirasa perlu menginventaris bahan tambahan makanan (BTM) penyebab positif palsu pada uji kualitatif boraks dengan filtrat ubi ungu (Ipomoea Batatas $L$ ).

\section{Metode Penelitian}

Pisau, parut, corong, beaker glass, kertas saring, pipet tetes, neraca analitik, gelas arloji, batang pengaduk, filler, pipet ukur, botol reagen, kertas $\mathrm{pH}$, dan tabung reaksi. Ubi jalar ungu, aquadest, Natrium Benzoat, Titanium Dioksida, Natrium Bikarbonat, Citroenzuur, Asam Askorbat, Natrium Tetraboraks, MSG (Monosodium Glutamat), Natrium Karbonat, Sodium Nitrat, Asam Benzoat, Pengenyal Daging, CMC (Carboxymethyl Cellulose), Skuestran Natrium Tripolifosfat.

Ditimbang boraks dengan menggunakan neraca analitik dan glass arloji sebanyak 1 gram dalam $10 \mathrm{ml}$. Kemudian dimasukkan ke dalam beaker glass dikocok hingga larutan dihomogen. Fltrat ubi jalar ungu $100 \%$ diperoleh dengan cara ubi jalar ungu dikupas dengan pisau, dicuci bersih dengan air mengalir, dipotong kecil-kecil dan diparut hingga halus. Ubi jalar ungu yang sudah di parut kemudian diperas untuk mendapatkan cairannya, kemudian disaring menggunakan kertas saring dan ditampung dalam beaker glass. Pembuatan sampel Bahan Tambahan Makanan (BTM) dilakukan dengan cara sebanyak masing-masing 1 gram Bahan Tambahan Makanan (BTM) ditimbang kemudian dimasukkan ke dalam beaker glass dan dilarutkan dengan $10 \mathrm{ml}$ aquadest kemudian di homogenkan. Larutan Kontrol menggunakan Natrium Tetraboraks dipipet sebanyak $2 \mathrm{ml}$ kedalam tabung reaksi kemudian di ukur $\mathrm{pH}$, lalu ditambahkan $2 \mathrm{ml}$ filtrat ubi ungu kemudian dihomogenkan. Pengujian sampel dialkukan dengan cara masing-masing sampel Bahan Tambahan Makanan yang akan diuji diukur $\mathrm{pH}$ masing-masing kemudian ditambahkan masing-masing filtrat ubi jalar ungu 100\% sebanyak $2 \mathrm{ml}$ kemudian diamati perubahan warna yang terjadi.

\section{Hasil Penelitian dan Pembahasan}

Berdasarkan hasil penelitian yang telah dilakukan di Laboratorium Kimia Jurusan Analis Kesehatan Mataram untuk mengetahui bahan tambahan makanan (BTM) penyebab positif palsu pada uji kualitatif boraks dengan filtrat ubi ungu (Ipomoea batatas L) terhadap 13 sampel Bahan Tambahan Makanan (BTM) terdiri dari 8 Bahan Tambahan Makanan (BTM) bersifat basa (Natrium Benzoat, Monosodium Glutamat, Natrium Tripoliposfat, Natrium Bikarbonat, Bikarbonat, Natrium Karbonat, Natrium Polipospat, dan Carboxyl Methyl Cellulose) dan 5 
Jurnal Analis Medika Biosains (JAMBS)

Vol.7, No.2, September 2020, pp. 87 - 92

ISSN: 2656-2456 (Online)

ISSN: 2356-4075 (Print)

Bahan Tambahan Makanan yang besifat asam (Citroenzuur, Asam Askorbat, Asam Benzoat, Sodium Nitrat, dan Titanium Dioksida) dan Natrium Tetraboraks sebagai kontrol . Dari 13 sampel Bahan Tambahan Makanan (BTM) setelah ditambahkan filtrat ubi ungu, 8 sampel bahan tambahan makanan memiliki perubahan warna yang sama dengan Natrium Tetraboraks (kontrol) dan 5 sampel Bahan Tambahan Makanan (BTM) lainnya memiliki perubahan warna yang berbeda dengan perubahan warna Natrium Tetraboraks (Kontrol). Perubahan warna yang sama dengan perubahan warna Natrium Tetraboraks terjadi pada 6 sampel senyawa Bahan Tambahan Makanan yang bersifat basa (Natrium Tripoliposfat, Natrium Bikarbonat, Bikarbonat, Natrium Karbonat, Natrium Polipospat, dan Carboxyl Methyl Cellulose) dan 2 sampel senyawa bersifat netral (Natrium Benzoat dan Monosodium Glutamat). Perubahan warna dari masing-masing sampel Bahan Tambahan Makanan yang digunakan ditunjukkan pada tabel 1 .

Dalam Peraturan Menteri Kesehatan RI No. 722/Menkes/Per/IX/88 dijelaskan bahwa BTM adalah bahan yang biasanya tidak digunakan sebagai pangan dan biasanya bukan merupakan ingredien khas pangan, mempunyai atau tidak mempunyai nilai gizi, yang dengan sengaja ditambahkan kedalam pangan. Tujuan penggunaan bahan tambahan makanan adalah untuk meningkatkan dan mempertahankan nilai gizi dan kualitas makanan.

Tabel.1 Hasil reaksi antara Bahan Tambahan Makanan dengan Filtrat Ubi Ungu (Ipomoea Batatas L) pada pH tertentu.

\begin{tabular}{llccc}
\hline No & \multicolumn{1}{c}{ Nama BTM } & PHasil Reaksi BTM + & Keterangan \\
\hline $\begin{array}{l}\text { Natrium Benzoat + Filtrat Ubi } \\
\text { Ungu }\end{array}$ & 7 & Biru Tua & Positif \\
\hline $\begin{array}{l}\text { Monosodium Glutamat + Filtrat } \\
\text { Ubi Ungu }\end{array}$ & 7 & Biru Tua & Positif \\
\hline $\begin{array}{l}\text { Natrium Tripoliposfat + Filtrat } \\
\text { Ubi Ungu }\end{array}$ & 8 & Biru Tua & Positif \\
\hline $\begin{array}{l}\text { Natrium Bikarbonat + Filtrat Ubi } \\
\text { Ungu }\end{array}$ & 9 & Biru Tua & Positif \\
\hline $\begin{array}{l}\text { Titanium Dioksida + Filtrat Ubi } \\
\text { Ungu }\end{array}$ & 6 & Coklat Tua & Negatif \\
\hline $\begin{array}{l}\text { Natrium Karbonat + Filtrat Ubi } \\
\text { Ungu }\end{array}$ & 9 & Biru Tua & Positif \\
\hline $\begin{array}{l}\text { Natrium Tripolifospat + Filtrat } \\
\text { Ubi Ungu }\end{array}$ & 9 & Biru Tua & Positif \\
\hline $\begin{array}{l}\text { Carboxyl Methyl Cellulose + } \\
\text { Filtrat Ubi Ungu }\end{array}$ & 9 & Piru Tua & \\
\hline
\end{tabular}


Jurnal Analis Medika Biosains (JAMBS)

Vol.7, No.2, September 2020, pp. 87 - 92

ISSN: 2656-2456 (Online)

ISSN: 2356-4075 (Print)

\begin{tabular}{lccc}
\hline $\begin{array}{l}\text { Natrium Tetraboraks + Filtrat } \\
\text { Ubi Ungu }\end{array}$ & 10 & Biru Tua & Positif \\
\hline Citroenzuur + Filtrat Ubi Ungu & 1 & Merah & Negatif \\
\hline $\begin{array}{l}\text { Asam askorbat + Filtrat Ubi } \\
\text { Ungu }\end{array}$ & 2 & Merah & Negatif \\
\hline $\begin{array}{l}\text { Sodium Nitrat + Filtrat Ubi } \\
\text { Ungu }\end{array}$ & 4 & Merah & Negatif \\
\hline Bikarbonat + Filtrat Ubi Ungu & 9 & Biru Tua & Positif \\
\hline
\end{tabular}

Sumber: Data primer 2019

Berdasarkan fungsinya, menurut peraturan Menkes No. 235 tahun 1979, BTM dapat dikelompokan menjadi 14 yaitu : antioksidan, antikempal, pengasam, penetral, enzim, pemanis buatan, pemutih dan pematang, penambah gizi, pengawet, pengemulsi, pemantap dan pengental, peneras, pewarna sintetis dan alami;,penyedap rasa dan aroma, dan sekuestran. BTM dikelompokan berdasarkan tujuan penggunaanya di dalam pangan. Pengelompokkan BTM yang diizinkan digunakan pada makanan dapat digolongkan sebagai : pewarna, pemanis buatan, pengawet, antioksidan, antikempal, penyedap dan penguat rasa serta aroma, pengatur keasaman, pemutih dan pamatang tepung, pengemulsi, pemantap dan pengental, pengeras, sekuestran, humektan, enzim dan penambah gizi.

Bahan Tambahan Makanan Natrium Benzoat biasa digunakan sebagai bahan pengawet dengan $\mathrm{pH} 7$ yang bersifat netral setelah ditambahkan filtrat ubi ungu terjadi perubahan warna menjadi biru tua. Dimana perubahan warna yang terjadi sama dengan Natrium tetraboraks setelah ditambahkan filtrat ubi ungu. Monosodium Glutamat merupakan zat padat yang tak berwarna yang biasa digunakan sebagai penguat rasa dengan $\mathrm{pH} 7$ bersifat netral setelah ditambahkan filtrat ubi ungu terjadi perubahan warna menjadi biru tua sama dengan natrium tetraboraks. Natrium Tripolipospat biasa digunakan sebagai pengawet daging dengan pH 8 sifat senyawa kimia basa lemah setelah ditambahkan filtrat ubi ungu terjadi perubahan warna menjadi biru tua.

Natrium Bikarbonat, Bikarbonat biasa digunakan sebagai pengembang dengan $\mathrm{pH} 9$ dengan sifat kimia basa lemah setelah ditambahkan filtrat ubi ungu terjadi perubahan warna menjadi biru tua. Natrium Karbonat dengan pH 9 dengan sifat kimia basa lemah setelah ditambahkan filtrat ubi ungu terjadi perubahan warna dari bening menjadi biru tua perubahan warna tersebut sama dengan natrium tetraboraks. Natrium Polipospat dengan $\mathrm{pH} 9$ dengan sifat kimia basa lemah setelah ditambahkan filtrat ubi ungu terjadi perubahan warna dari bening menjadi biru tua perubahan warna tersebut sama dengan natrium tetraboraks.

Berdasarkan hasil penelitian ini menunjukkan bahwa kondisi pH pada sampel Bahan Tambahan Makanan mempengaruhi hasil pemeriksaan deteksi boraks dengan menggunakan filtrat ubi ungu (Ipomoea batatas $L$ ).

Adapun dari penelitian yang telah dilakukan pada sampel Bahan Tambahan Makanan dalam keadaan basa menunjukkan perubahan warna menjadi biru tua setelah ditambahkan filtrat ubi ungu (Ipomoea Batatas L) perubahan warna tersebut menunjukkan adanya reaksi antara senyawa antosianin dengan senyawa garam natrium, 
Jurnal Analis Medika Biosains (JAMBS)

Vol.7, No.2, September 2020, pp. 87 - 92

ISSN: 2656-2456 (Online)

ISSN: 2356-4075 (Print)

perubahan warna tersebut sama dengan natrium tetraboraks setelah ditambahkan filtrat ubi ungu. Sedangkan senyawa kimia yang bersifat asam terbentuk perubahan warna menjadi merah. Perubahan warna tersebut menunjukkan bahwa dari hasil tersebut memberikan hasil yang tidak valid pada pendeteksian boraks pada makanan dengan menggunakan filtrat ubi ungu (Ipomoea batatas $L$ ) dimana dipengaruhi oleh adanya senyawa pengganggu garam natrium yang mempengaruhi hasil uji kualitatif boraks dengan filtrat ubi ungu dengan memberikan hasil positif palsu. Sedangkan menurut (Khopkar, 2003) Perubahan warna pada suasana asam basa tersebut karena disebabkan oleh resonansi isomer elektron sehingga berbagai indikator mempunyai tetapan ionisasi yang berbeda dan mengakibatkan warna pada range $\mathrm{pH}$ yang berbeda.

Dari penelitian lain yang terkait pemanfaatan senyawa antosianin dalam ekstrak ubi ungu (Ipomoea batatas L) digunakan sebagai indikator asam dan basa. Dimana antosianin sangat dipengaruhi oleh $\mathrm{pH}$ dan tingkat keasaman dalam keadaan asam antosianin berwarna merah sedangkan dalam keadaan basa antosianin berwarna biru - ungu kadang berwarna kuning dan akan lebih stabil dalam keadaan asam (Arja, 2013).

\section{Kesimpulan}

Berdasarkan hasil penelitian yang telah dilakukan dapat disimpulkan bahwa Bahan tambahan makanan dengan hasil positif palsu pada uji kualitatif boraks dengan filtrat ubi ungu (Ipomoea Batatas L) yaitu Natrium Benzoat, Monosodium Glutamat, Natrium Tripoliposfat, Natrium Bikarbonat, Bikarbonat, Natrium Karbonat, Natrium Polipospat, dan Carboxyl Methyl Cellulose.

\section{Daftar Pustaka}

Arja, F. S., Darwis, D. \& Santoni, A. (). Isolasi, identifikasi, dan uji antioksidan senyawa antosianin dari buah sikaduduk (melastoma malabathricum 1) serta aplikasi sebagai pewarna alami. Jurnal Kimia Unand,. 2013. 2(1): 124-127.

Halim, Azhar A. Boron Removal From Aquaous Solution Using Curcumin-Aided Electrocoagulation. MiddleEast. 2012.

Khopkar, S.M. Kimia Analitis. 2003 Jakarta : UI-Press. Halaman 419

Neny Rochyani, Muhammad Rizki Akbar, Yongky Randi. Pembuatan Media Uji Formalin dan Boraks Menggunakan Zat Antosianin dengan Pelarut ETanol 70\%. Jurnal Redoks. 2017. Vol (1) hal : 28- 35.

Notoatmodjo, S .2005. Promosi Kesehatan teori dan aplikasinya.Jakarta: Rineka Cipta.

Peraturan Menteri Kesehatan RI No. 722/Menkes/Per/IX/88. 1999.

Widya, N. dan Martini. Pemberian Chitosan sebagai Bahan Pengawet Alami dan Pengaruhnya terhadap Kandungan Protein dan Organoleptik pada Bakso Udang. 2006. UMS Press. 